\title{
Polemik Pencatatan Anak Dari Nikah Siri
}

\author{
Agus Manurung ${ }^{1}$, Lusia Sulastri $^{2}$ \\ ${ }^{1}$ Program Doktor, IAIN Syekh Nurjati Cirebon \\ ${ }^{2}$ Fakultas Hukum, Universitas Bhayangkara Jakarta Raya \\ Email: 3bhe89.gusman@gmail.com; lusia.sulastri@dsn.ubharajaya.ac.id
}

Received : 17 Oct 2021 | Revised : 28 Nop 2021 | Accepted : 2 Dec 2021 | Published : 9 Dec 2021

\begin{abstract}
The current unregistered married couple can have a new KK provided that the data for the Statement of Absolute Responsibility (SPTJM) form refers to Permendagri No. 9/2016 concerning the Acceleration of Increasing the Coverage of Birth Certificate Ownership. The SPTJM document itself consists of two things. First, the SPTJM of the Truth of Birth Data made by biological parents/guardians/applicants with full responsibility for the correctness of a person's birth data with the knowledge of two witnesses. Second, the SPTJM Truth as a Married Couple made by the biological parents/guardians/applicants with full responsibility for the status of a person's marital relationship with the knowledge of two witnesses. The registration of children from unregistered marriages through a Statement of Absolute Responsibility (SPTJM) refers to Permendagri No. 9/2016 concerning the Acceleration of Increasing the Coverage of Birth Certificate Ownership still causes legal problems, nonfulfillment of marriage certificates/marriage certificate quotations and family relationship status in KK that do not show marital relationship status as husband and wife, then the data recorded in the child's birth certificate quote is only only his mother's name. Not at the same time include the name of the father as in a legal marriage. So that the child still needs to prove who the father is if needed in the future. Apart from that, there will be many obstacles in the effort to prove because the existence of a new KK through the SPTJM document has weak evidentiary power because it is limited to one-sided acknowledgment of the signatories. As well as other obstacles deliberately caused by the litigants. The position of Siri's own wife is very vulnerable to legal protection as well. In the absence of legal status as a legal wife, there has not been a reciprocal legal relationship of rights and obligations as a married couple. The fulfillment of the rights and obligations of each cannot use the basis of the demands for fulfillment of the law but is only limited to the stages of good faith by each party.
\end{abstract}

Keywords: Registration, Children, and Unregistered Marriage

\begin{abstract}
ABSTRAK
Pasangan nikah siri saat ini bisa memiliki KK baru dengan syarat melengkapi data formulir Surat Pernyataan Tanggung Jawab Mutlak (SPTJM) adalah mengacu Permendagri No. 9/2016 tentang Percepatan Peningkatan Cakupan Kepemilikan Akta Kelahiran. Dokumen SPTJM sendiri terdiri dari dua hal. Pertama, SPTJM Kebenaran
\end{abstract}


Data Kelahiran yang dibuat orang tua kandung/wali/pemohon dengan tanggung jawab penuh atas kebenaran data kelahiran seseorang dengan diketahui oleh dua orang saksi. Kedua, SPTJM Kebenaran Sebagai Pasangan Suami Istri yang dibuat oleh orang tua kandung/wali/pemohon dengan tanggung jawab penuh atas status hubungan perkawinan seseorang dengan diketahui dua orang saksi. Pencatatan anak hasil nikah siri melalui Surat Pernyataan Tanggung Jawab Mutlak (SPTJM) adalah mengacu Permendagri No. 9/2016 tentang Percepatan Peningkatan Cakupan Kepemilikan Akta Kelahiran masih menimbulkan permasalahan hukum, tidak terpenuhinya akta nikah/kutipan akta perkawinan dan status hubungan keluarga pada KK yang tidak menunjukkan status hubungan perkawinan sebagai suami istri, maka data yang dicatat dalam kutipan akta kelahiran sang anak hanya nama ibu kandungnya saja. Tidak sekaligus mencantumkan nama bapaknya sebagaimana halnya dalam perkawinan yang sah. Sehingga sang anak masih memerlukan pembuktian siapakah bapaknya apabila diperlukan di kemudian hari. Disamping dalam upaya pembuktian akan banyak mengalami hambatan karena keberadaan KK baru melalui dokumen SPTJM memiliki kekuatan pembuktian yang lemah karena sebatas pengakuan sepihak penandatangan. Serta halangan halangan lain yang sengaja ditimbulkan para pihak yang berperkara. Kedudukan istri siri sendiri sangat rentan terhadap perlindungan hukumnya pula. Tidak adanya status kedudukan hukum sebagai istri yang sah maka belum timbul hubungan hukum timbal balik hak dan kewajiban sebagai pasangan suami istri. Pemenuhan hak dan kewajiban masing masing belum dapat menggunakan dasar tuntutan pemenuhan hukum melainkan hanya sebatas tahapan iktikad baik masing masing pihak.

Kata Kunci: Pencatatan, Anak, dan Nikah siri

\section{PENDAHULUAN}

R. Soetojo Prawirohamidjijo dalam Mertokusumo menyatakan bahwa perkawinan adalah "persekutuan antara seorang pria dan seorang wanita yang diakui oleh Negara untuk hidup bersama/bersekutu yang kekal" (Mertokusumo, 2002: 61). Artinya bahwa perkawinan sebagai lembaga hukum baik karena apa yang ada di dalamnya, maupun karena apa yang terdapat di dalamnya (Mertokusumo, 2002: 61). Menurut bahasa Arab perkawinan juga disebut dengan al-nikah (Yunus, 1973: 468). Al-nikah yang bermakna al-wathi' dan al-dammu wa al-tadakhul, terkadang juga disebut dengan aldammu wa al-jam'u atau ibarat 'an al-wath wa al- 'aqd yang bermakna bersetubuh, berkumpul dan akad (Nuruddin \& Tarigan, 2004: 38).

Salah satu kontek pernikahan yang juga menjadi fenomena di dalam masyarakat adalah nikah siri. Nikah siri dalam pandangan masyarakat umum setidaknya dapat dijelaskan sebagai berikut:

"Pertama, Nikah tanpa wali. Nikah semacam ini dilakukan secara rahasia (siri) karena wali pihak perempuan mungkin tidak setuju; atau karena menganggap sahnya Nikah tanpa wali; atau hanya karena ingin memuaskan nafsu syahwat belaka tanpa mengindahkan lagi ketentuan syariat. Kedua; Nikah yang sah secara agama dan atau adat istiadat, namun tidak diumumkan pada masyarakat umum, dan juga tidak dicatatkan secara resmi dalam lembaga pencatatan negara, yaitu Kantor Urusan Agama (KUA) bagi yang beragama Islam dan Kantor Catalan Sipil (KCS) bagi yang beragama non Islam. Ada kerena faktor 
biaya, tidak mampu membiayai administrasi pencatatan; ada juga disebabkan karena takut ketahuan melanggar aturan yang melarang pegawai negeri menikah lebih dari satu (poligami) tanpa seizin pengadilan, dan sebagainya. Ketiga; Nikah yang dirahasiakan karena pertimbangan-pertimbangan tertentu, misalnya karena takut menerima stigma negatif dari masyarakat yang terlanjur menganggap tabu Nikah siri atau karena pertimbangan-pertimbangan lain yang akhirnya memaksa seseorang merahasiakannya (Happy Susanto, 2007).”

Saat ini eksistensi nikah siri masih mendapat stigma negatif dari masyarakat. Keberadaan stigma negatif tersebut, menyebabkan masih maraknya pemahaman bahwa pelaku nikah siri akan mengalami hambatan serius saat mengurus Kartu Keluarga (KK) yang baru. Hal ini karena dalam pembuatan KK yang mencantumkan nama pasangan nikah siri, tidak ada bukti pernikahan resmi diantara mereka. Kartu Keluarga dimaksud menjadi penting artinya di kemudian hari sebagai syarat pembuatan Akta Kelahiran bagi anaknya yang lahir dari pernikahan siri.

Berdasarkan permasalahan administrasi kependudukan tersebut, Dirjen Kementerian Dalam Negeri (Kemendagri) Prof. Zudan Arif Fakrulloh menegaskan bahwa pasangan suami istri yang menikah secara siri tetap bisa mendapatkan kartu keluarga (KK) (Rizal, https://www.kompas.com). Ia menambahkan bahwa, pasangan nikah siri bisa memiliki KK baru dengan syarat melengkapi data formulir Surat Pernyataan Tanggung Jawab Mutlak (SPTJM) adalah mengacu Permendagri No. 9/2016 tentang Percepatan Peningkatan Cakupan Kepemilikan Akta Kelahiran. Dokumen SPTJM sendiri terdiri dari dua hal. Pertama, SPTJM Kebenaran Data Kelahiran yang dibuat orang tua kandung/wali/pemohon dengan tanggung jawab penuh atas kebenaran data kelahiran seseorang dengan diketahui oleh dua orang saksi. Kedua, SPTJM Kebenaran Sebagai Pasangan Suami Istri yang dibuat oleh orang tua kandung/wali/pemohon dengan tanggung jawab penuh atas status hubungan perkawinan seseorang dengan diketahui dua orang saksi.

Dokumen SPTJM ini menjadi sangat penting fungsinya sebagai syarat pengganti kelengkapan tidak adanya Akta Nikah/Kutipan Akta Perkawinan resmi yang diperlukan untuk mendapatkan dokumen Akta Kelahiran anak dari pasangan nikah siri. Hal ini tercantum dalam ketentuan Permendagri No. 9/2016 tentang Percepatan Peningkatan Cakupan Kepemilikan Akta Kelahiran :

Pasal 5 ayat (2) menyatakan :

"Dalam hal persyaratan berupa akta nikah/kutipan akta perkawinan sebagaimana dimaksud dalam Pasal 3 ayat (1) huruf b tidak terpenuhi, dan status hubungan dalam keluarga pada KK menunjukkan status hubungan perkawinan sebagai suami isteri, dicatat dalam register akta kelahiran dan kutipan akta kelahiran dengan elemen data sebagaimana tercantum dalam lampiran yang merupakan bagian tidak terpisahkan dari Peraturan Menteri ini."

Pasal 3 ayat (1) menyebutkan :

"Persyaratan pencatatan kelahiran sebagaimana dimaksud dalam Pasal 2 huruf a dengan memenuhi syarat berupa:

a. surat keterangan lahir dari dokter/bidan/penolong kelahiran;

b. akta nikah/kutipan akta perkawinan;

c. KK dimana penduduk akan didaftarkan sebagai anggota keluarga;

d. KTP-el orang tua/wali/pelapor; atau

e. paspor bagi WNI bukan penduduk dan orang asing." 
Pasal 4 ayat (2) menyebutkan :

"Dalam hal persyaratan berupa akta nikah/kutipan akta perkawinan sebagaimana dimaksud dalam Pasal 3 ayat (1) hurufb tidak terpenuhi, pemohon melampirkan SPTJM kebenaran sebagai pasangan suami isteri.'

Pengurusan Akta Kelahiran anak pasangan nikah siri ini dapat dilakukan menggunakan SPTJM Kebenaran Sebagai Suami Istri didukung dengan KK, yang selanjutnya dicatat dalam register akta kelahiran dan kutipan akta kelahiran dengan elemen data sebagaimana tercantum dalam lampiran yang merupakan bagian tidak terpisahkan dari Permendagri No. 9/2016 tersebut. Prof Zudan menambahkan, dalam KK baru tersebut akan dicantumkan keterangan "nikah atau kawin belum tercatat".

Dengan demikian tidak tertutup kemudahan membuat Akta Kelahiran seorang anak meskipun orang tuanya nikah siri. Hal ini karena tujuan terbitnya Permendagri No. 9/2016 tentang Percepatan Peningkatan Cakupan Kepemilikan Akta Kelahiran ini adalah bahwa, semua warga negara wajib tercatat dalam KK, bagi si anak setelah memiliki Akta Kelahiran akan tercatat dalam KK. Akan tetapi Kartu Keluarga "baru" yang diperoleh setelah melalui dokumen SPTJM Kebenaran Sebagai Pasangan Suami Istri masih mengundang pertanyaan dalam praktek. Alasannya, salah satu faktor penyebab nikah siri adalah tidak diizinkannya suami menikah lagi oleh pasangannya, atau tidak mendapatkan persetujuan Pengadilan. Dalam hal ini harus dipastikan terlebih dahulu bagaimanakah status Kartu Keluarga saat dengan istri yang lama. Karena kecil kemungkinannya nama istri yang lama akan tetap tercatat pada KK dengan istri siri yang baru.

Ataukah KK yang lama harus dicabut dan dinyatakan tidak berlaku lagi ? Seandainya demikian, bagaimana status hubungan keluarga dengan istri lama sebagaimana tercatat dalam KK sebelumnya, karena sebenarnya pernikahan yang lama masih berlangsung dan tidak ada perceraian. Pemaksaan pencabutan KK yang lama ini tentunya menimbulkan permasalahan lain yang sangat serius sehingga menjurus kepada tindak pidana pemalsuan surat. Oleh karenanya dapat dipahami bahwa pembuatan KK baru ini lebih dimungkinkan hanya bagi pasangan nikah siri yang memang tidak memiliki pasangan sebelumnya, atau bukan untuk perkawinan yang memiliki lebih dari satu pasangan.

Keberadaan dua orang saksi dalam dokumen SPTJM juga harus mendapatkan tekanan penjelasan. Kualifikasi dua saksi tersebut adalah penduduk yang mengetahui saat dokumen SPTJM tersebut dibuat, sehingga tidak berhubungan dengan pembuktian kapan nikah siri tersebut dilakukan. Pembebanan tanggung jawab sepenuhnya tetap dibebankan terhadap orang tua kandung/wali/pemohon yang membuat pernyataan SPTJM sehingga kekuatan pembuktiannya masih lemah dan tidak dapat mengikat kepada pihak lain. Penting disadari bahwa sebenarnya urgensi dokumen SPTJM adalah demi kepentingan sang anak dari pernikahan siri yang harus tercatat dalam KK sebagai warga negara.

\section{PEMBAHASAN}

\section{Keterbatasan Status Anak dan Istri Siri}

Salah satu hak asasi yang dijamin dalam konstitusi tersebut adalah berkenaan dengan hak mengenai status kewarganegaraan seseorang sebagaimana diatur dalam Pasal 28D ayat (4) UUD 1945 yang menyebutkan bahwa setiap orang berhak atas status kewarganegaraan. Ketentuan tersebut berarti bahwa negara berdasarkan UUD 1945 pada hakikatnya berkewajiban memberikan perlindungan dan pengakuan terhadap 
penentuan status kewarganegaraan yang dialami oleh penduduk Indonesia yang berada di dalam dan/atau di luar wilayah Negara Kesatuan Republik Indonesia. Hal ini juga diperkuat berdasarkan Pasal 28D ayat (1) yang menyatakan bahwa setiap orang berhak atas pengakuan, jaminan, perlindungan, dan kepastian hukum yang adil serta perlakuan yang sama di hadapan hukum.

Untuk dapat lebih menjamin hak warga negara berkaitan dengan status kewarganegaraan penduduk serta memberikan perlindungan dan pengakuan terhadap penentuan status kewarganegaraan yang dialami oleh penduduk Indonesia, maka perlu dilakukan pengaturan tentang administrasi kependudukan dalam bentuk undangundang. Hal ini sebagaimana juga telah diamanatkan dalam Pasal 26 ayat (3) UUD 1945 hasil amandemen yang menyatakan bahwa hal-hal mengenai warga negara dan penduduk diatur dengan undang-undang.

Amanat sebagaimana terdapat dalam UUD 1945 tersebut, kemudian direspon oleh legislatif dengan membentuk Undang-Undang Nomor 23 Tahun 2006 tentang Administrasi Kependudukan. Dibentuknya undang-undang ini juga dikarenakan bahwa peraturan perundang-undangan mengenai Administrasi Kependudukan yang ada tidak sesuai lagi dengan tuntutan pelayanan Administrasi Kependudukan yang tertib dan tidak diskriminatif sehingga diperlukan pengaturan secara menyeluruh untuk menjadi pegangan bagi semua penyelenggara negara yang berhubungan dengan kependudukan.

Negara Kesatuan Republik Indonesia berdasarkan Pancasila dan UndangUndang Dasar Negara Republik Indonesia Tahun 1945 pada hakikatnya berkewajiban untuk memberikan perlindungan dan pengakuan terhadap penentuan status pribadi dan status hukum setiap Peristiwa Kependudukan dan Peristiwa Penting yang dialami oleh penduduk yang berada di dalam dan atau di luar wilayah Negara Kesatuan Republik Indonesia.

Administrasi kependudukan memuat tentang Peristiwa Kependudukan dan Peristiwa Penting, yang dimaksud Peristiwa Kependudukan antara lain perubahan alamat, pindah datang untuk menetap, tinggal terbatas, serta perubahan status orang asing tinggal terbatas menjadi tinggal tetap. Sedangkan Peristiwa Penting seperti kelahiran, lahir mati, kematian, perkawinan, dan perceraian, termasuk pengangkatan, pengakuan, dan pengesahan anak, serta perubahan status kewarganegaraan, ganti nama dan peristiwa penting lainnya yang dialami oleh seseorang merupakan kejadian yang harus dilaporkan karena membawa implikasi perubahan data identitas atau surat keterangan kependudukan. Dengan demikian, setiap Peristiwa Kependudukan dan Peristiwa Penting memerlukan bukti yang sah untuk dilakukan pengadministrasian dan pencatatan sesuai dengan ketentuan undang-undang.

Sesuai dengan perubahan dan perkembangan yang terjadi dalam masyarakat Indonesia maka masyarakat Indonesia sadar bahwa seseorang perlu memiliki bukti tertulis dalam menentukan status seseorang atas kejadian-kejadian atau peristiwaperistiwa, misalnya: perkawinan, kelahiran, kematian, pengakuan anak, pengesahan anak, perceraian, kematian maupun pergantian nama. Untuk memiliki status tersebut, maka orang tersebut harus mendaftarkan peristiwa atau kejadian itu pada Lembaga Catatan Sipil, dengan demikian orang tersebut akan memperoleh bukti tertulis yang berupa Akta Catatan Sipil.

Semua akta yang dikeluarkan oleh Catatan Sipil ialah merupakan akta otentik yang mengandung kebenaran murni, mempunyai kekuatan dan kepastian hukum, tidak dapat dikatakan palsu sebelum dinyatakan oleh Pengadilan Negeri dengan ketetapan atau keputusannya, dan tidak dapat diralat atau dibatalkan atau diperbaharui, selain izin Pengadilan Negeri serta mengikat semua pihak. Dengan demikian Akta Catatan 
Sipil tersebut merupakan hal yang sangat menentukan akan kebenaran dari suatu permasalahan apabila diperkarakan. Dan dalam lingkungan internasional Akta Catatan Sipil mendapat pengakuan yang sah (Situmorang dan Sitanggang, 1991: 3).

Perkawinan merupakan salah satu peristiwa hukum yang harus di catat dalam administrasi kependudukan. Hal ini karena perkawinan melahirkan status hubungan hukum seseorang, apalagi jika dikemudian hari melahirkan anak, sehingga peristiwa hukum perkawinan sejatinya menjadi induk dari peristiwa hukum lainnya yang lahir dalam lapangan hukum kekeluargaan. Oleh karena itu menurut R. Soetojo Prawirohamidjijo, nikah adalah persekutuan antara seorang pria dan seorang wanita yang diakui oleh Negara untuk hidup bersama/bersekutu yang kekal" (Mertokusumo, 2002: 61). Namun demikian adapula fenomena yang disampaikan Happy Susanto, bahwa terdapat fenomena nikah siri, lalu bagaimana negara harus melindungi peristiwa hukum tersebut dan bagaimana negara harus mencatat peristiwa hukum tersebut, jika nikah siri adalah pernikahan yang dirahasiakan.

Sifat kerahasiaan nikah siri banyak menimbulkan permasalahan, mulai dari isu perselingkuhan, hingga sulitnya mendapatkan bukti administrasi kependudukan seperti KK, akta kelahiran bahkan hingga akibat hukum berupa hubungan hukum asal usul keluarga bahkan pewarisan. Padahal peristiwa kelahiran merupakan peristiwa hukum yang memerlukan adanya suatu pengaturan yang tegas, jelas dan tertulis sehingga terciptanya kepastian hukum dalam masyarakat. Oleh karena itu peristiwa kelahiran perlu mempunyai bukti yang otentik, karena untuk membuktikan identitas seseorang yang pasti dan sah adalah dapat kita lihat dari akta kelahiran yang di keluarkan oleh suatu lembaga yang berwenang mengeluarkan akta tersebut (Prodjohamidjojo, 2004: 33).

Tidak terpenuhinya akta nikah/kutipan akta perkawinan dan status hubungan keluarga pada KK yang tidak menunjukkan status hubungan perkawinan sebagai suami istri, maka data yang dicatat dalam kutipan akta kelahiran sang anak hanya nama ibu kandungnya saja. Tidak sekaligus mencantumkan nama bapaknya sebagaimana halnya dalam perkawinan yang sah. Sehingga sang anak masih memerlukan pembuktian siapakah bapaknya apabila diperlukan di kemudian hari.

Berbeda halnya apabila KK tersebut menyatakan status hubungan bapak anak yang didukung melalui Akta Perkawinan sah orang tuanya, kekuatan pembuktian siapa bapaknya didukung dengan alat bukti Surat dan bukan sebatas alat bukti Petunjuk bahwa sang anak adalah anak yang sah. Menurut DY Witanto (2012) :

"Anak sah menempati kedudukan (strata) yang paling tinggi dan paling sempurna di mata hukum dibandingkan dengan anak dalam kelompok-kelompok yang lain, karena anak sah menyandang seluruh hak yang diberikan oleh hukum, antara lain hak waris dalam peringkat yang paling tinggi di antara golongangolongan ahli waris yang lain, hak sosial di mana ia akan mendapatkan status yang terhormat di tengah-tengah lingkungan masyarakat, hak alimentasi, hak untuk mendapatkan penamaan ayah dalam akta kelahiran dan hak-hak lainnya."

Berdasarkan hal tersebut maka, kepentingan hukum si anak dari perkawinan siri menjadi kurang terlindungi. Meskipun terdapat Putusan Mahkamah Konstitusi No. 46/PUU- VIII/2010, yang amarnya menyatakan :

"Anak yang dilahirkan di luar perkawinan mempunyai hubungan perdata dengan ibunya dan keluarga ibunya serta dengan laki-laki sebagai ayahnya yang dapat dibuktikan berdasarkan ilmu pengetahuan dan teknologi dan atau alat bukti lain menurut hukum mempunyai hubungan darah, termasuk hubungan perdata dengan keluarga ayahnya". 
Tetapi dalam banyak praktek jarang ditemukan pembagian waris secara suka rela oleh para ahli waris yang ada terhadap anak dari perkawinan siri ini. Pada akhirnya terpaksa ditempuh melalui Gugatan pada Pengadilan yang menimbulkan biaya sosial sangat tinggi. Disamping dalam upaya pembuktian akan banyak mengalami hambatan karena keberadaan KK baru melalui dokumen SPTJM memiliki kekuatan pembuktian yang lemah karena sebatas pengakuan sepihak penandatangan. Serta halangan halangan lain yang sengaja ditimbulkan para pihak yang berperkara.

Kedudukan istri siri sendiri sangat rentan terhadap perlindungan hukumnya pula. Tidak adanya status kedudukan hukum sebagai istri yang sah maka belum timbul hubungan hukum timbal balik hak dan kewajiban sebagai pasangan suami istri. Pemenuhan hak dan kewajiban masing masing belum dapat menggunakan dasar tuntutan pemenuhan hukum melainkan hanya sebatas tahapan iktikad baik masing masing.

Dalam kaitan uji materiil Pasal 1 ayat (2) UU No. 1/1974 tentang Perkawinan yang memeriksa tentang kewajiban pencatatan pernikahan, melalui Putusan Mahkamah Konstitusi No. 46/PUU- VIII/2010, mahkamah menilai bahwa faktor yang menentukan sahnya perkawinan adalah syarat-syarat yang ditentukan oleh agama dari masing masing pasangan calon mempelai. Diwajibkannya pencatatan perkawinan oleh negara melalui peraturan perundang-undangan merupakan kewajiban administratif. Sekiranya pencatatan dimaksud dianggap sebagai pembatasan, pencatatan demikian menurut Mahkamah Konstitusi tidak bertentangan dengan ketentuan konstitusional karena pembatasan ditetapkan dengan undang-undang dan dilakukan dengan maksud semata-mata untuk menjamin pengakuan serta penghormatan atas hak dan kebebasan orang lain, dan untuk memenuhi tuntutan yang adil sesuai dengan pertimbangan moral, nilai-nilai agama, keamanan, dan ketertiban umum dalam suatu masyarakat demokratis. Sehingga Mahkamah Konstitusi menilai pasal tersebut tidak bertentangan dengan Undang-Undang Dasar 1945.

Oleh karenanya secara norma yuridis kewajiban pencatatan pernikahan sudah dinyatakan final dan sebatas dinilai sebagai kewajiban administratif. Hal ini tentunya kontra produktif dari sudut pandang upaya pencegahan nikah siri yang dinilai sangat merugikan kepentingan hukum pasangan terutama dari pihak istri, dan anak yang dilahirkan dari pernikahan siri tersebut. Sementara peristiwa nikah siri ini terus saja terjadi di masyarakat.

\section{Norma Hukum, Norma Sosial, dan Norma Teologis}

Pasal 1 ayat (3) UUD 1945 setelah amandemen dirumuskan bahwa "Negara Indonesia adalah negara hukum". Penegasan "Negara Indonesia" merupakan penjelasan yang sudah dapat dipahami sebagai identitas, bahwa negara yang diatur dalam konstitusi ini bernama "Indonesia". Selain itu artinya bahwa dalam penyelenggaraan kehidupan berbangsa dan bernegara terdapat aturan-aturan hukum yang mengaturnya. Undang-undang Dasar itu sendiri merupakan sebagian dari hukum dasar yang tertulis. Selain Undang-undang Dasar, terdapat aturan-aturan dasar yang timbul dan terpelihara dalam praktik penyelenggaraan negara meskipun tidak tertulis. Dalam penyelenggaraan negara, sebagian besar aturan dituangkan dalam bentuk hukum tertulis, mulai dari Undang-undang Dasar, Undang-undang, Peraturan Daerah, sampai pada peraturan yang paling rendah kedudukannya. Sementara itu, keberadaan hukum tidak tertulis dalam praktik ketatanegaraan lahir untuk melengkapi hal-hal yang tidak diatur dalam hukum tertulis 
Pada dasarnya, dalam negara hukum segenap penyelenggaraan urusan kenegaraan didasarkan atas hukum. Menurut Wirjono Prodjodikoro dalam buku Nuktoh Arfani Kurde yang berjudul "Telaah Kritis Teori Negara Hukum”, negara hukum berarti suatu negara yang di dalam wilayahnya :

a. Semua alat-alat perlengkapan dari negara khususnya alat-alat perlengkapan dari pemerintah dalam tindakannya baik terhadap warga negara maupun dalam saling berhubungan masing-masing tidak boleh sewenang-wenang, melainkan harus memperhatikan peraturan-peraturan hukum yang berlaku.

b. Semua orang (penduduk) dalam hubungan kemasyarakatan harus tunduk pada peraturan-peraturan hukum yang berlaku (Kurde, 2005: 25).

c. Semua alat-alat perlengkapan dari negara khususnya alat-alat perlengkapan dari pemerintah dalam tindakannya baik terhadap warga negara maupun dalam saling berhubungan masing-masing tidak boleh sewenang-wenang, melainkan harus memperhatikan peraturan-peraturan hukum yang berlaku.

d. Semua orang (penduduk) dalam hubungan kemasyarakatan harus tunduk pada peraturan-peraturan hukum yang berlaku (Kurde, 2005: 25).

Menurut Arief Sidharta, Scheltema, merumuskan pandangannya tentang unsurunsur dan asas-asas Negara Hukum itu secara baru, yaitu meliputi 5 (lima) hal sebagai berikut:

a. Pengakuan, penghormatan, dan perlindungan Hak Asasi Manusia yang berakar dalam penghormatan atas martabat manusia (human dignity).

b. Berlakunya asas kepastian hukum. Negara Hukum untuk bertujuan menjamin bahwa kepastian hukum terwujud dalam masyarakat. Hukum bertujuan untuk mewujudkan kepastian hukum dan prediktabilitas yang tinggi, sehingga dinamika kehidupan bersama dalam masyarakat bersifat 'predictable'. Asas-asas yang terkandung dalam atau terkait dengan asas kepastian hukum itu adalah:

1) Asas legalitas, konstitusionalitas, dan supremasi hukum.

2) Asas undang-undang menetapkan berbagai perangkat peraturan tentang cara pemerintah dan para pejabatnya melakukan tindakan pemerintahan.

3) Asas non-retroaktif perundang-undangan, sebelum mengikat undangundang harus lebih dulu diundangkan dan diumumkan secara layak.

4) Asas peradilan bebas, independent, imparial, dan objektif, rasional, adil dan manusiawi.

5) Asas non-liquet, hakim tidak boleh menolak perkara karena alasan undangundangnya tidak ada atau tidak jelas.

6) Hak asasi manusia harus dirumuskan dan dijamin perlindungannya dalam undang-undang atau UUD.

c. Berlakunya Persamaan (Similia Similius atau Equality before the Law) dalam Negara Hukum, Pemerintah tidak boleh mengistimewakan orang atau kelompok orang tertentu, atau memdiskriminasikan orang atau kelompok orang tertentu. Di dalam prinsip ini, terkandung (a) adanya jaminan persamaan bagi semua orang di hadapan hukum dan pemerintahan, dan (b) tersedianya mekanisme untuk menuntut perlakuan yang sama bagi semua warga Negara.

d. Asas demokrasi dimana setiap orang mempunyai hak dan kesempatan yang sama untuk turut serta dalam pemerintahan atau untuk mempengaruhi tindakantindakan pemerintahan. Untuk itu asas demokrasi itu diwujudkan melalui beberapa prinsip, yaitu: 
1) Adanya mekanisme pemilihan pejabat-pejabat publik tertentu yang bersifat langsung, umum, bebas, rahasia, jujur dan adil yang diselenggarakan secara berkala.

2) Pemerintah bertanggungjawab dan dapat dimintai pertanggungjawaban oleh badan perwakilan rakyat.

3) Semua warga Negara memiliki kemungkinan dan kesempatan yang sama untuk berpartisipasi dalam proses pengambilan keputusan politik dan mengontrol pemerintah.

4) Semua tindakan pemerintahan terbuka bagi kritik dan kajian rasional oleh semua pihak.

5) Kebebasan berpendapat/berkeyakinan dan menyatakan pendapat.

6) Kebebasan pers dan lalu lintas informasi.

7) Rancangan undang-undang harus dipublikasikan untuk memungkinkan partisipasi rakyat secara efektif.

e. Pemerintah dan Pejabat mengemban amanat sebagai pelayan masyarakat dalam rangka mewujudkan kesejahteraan masyarakat sesuai dengan tujuan bernegara yang bersangkutan. Dalam asas ini terkandung hal-hal sebagai berikut:

1) Asas-asas umum peerintahan yang layak.

2) Syarat-syarat fundamental bagi keberadaan manusia yang bermartabat manusiawi dijamin dan dirumuskan dalam aturan perundang-undangan, khususnya dalam konstitusi.

3) Pemerintah harus secara rasional menata tiap tindakannya, memiliki tujuan yangn jelas dan berhasil guna (doelmatig). Artinya, pemerintahan itu harus diselenggarakan secara efektif dan efisien (Sidharta, 2004 :124).

Masalah kependudukan yang sering dihadapi tidak terlepas kaitannya dengan kondisi tertib administrasi kependudukan, baik dalam konteks pendaftaran maupun pencatatannya dalam rangka memberikan status kepastian hukum keperdataan kepada setiap orang. Administrasi kependudukan diarahkan untuk :

a. Memenuhi hak asasi setiap orang di bidang administrasi kependudukan tanpa diskriminasi dengan pelayanan publik yang profesional ;

b. Meningkatkan kesadaran penduduk akan kewajibannya untuk berperan serta dalam pelaksanaan administrasi kependudukan;

c. Memenuhi data statistik secara nasional mengenai peristiwa kependudukan dan peristiwa penting ;

d. Mendukung perumusan kebijakan dan perencanaan pembangunan secara nasional, regional, serta lokal; dan

e. Mendukung pembangunan sistem administrasi kependudukan.

Administrasi kependudukan merupakan sarana Memenuhi hak asasi setiap orang di bidang administrasi kependudukan tanpa diskriminasi dengan pelayanan publik yang profesional, namun kerap kali tersandra dengan skema hukum yang rumit, misalnya dualisme hukum pencatatan pernikahan dalam Pasal 2 ayat (1) dan ayat (2) UU No. 1/1974 bahwa, di satu sisi sahnya perkawinan adalah menurut agama dan kepercayaannya masing-masing, di sisilain perkawinan itu harus dicatatkan. Dualisme ini pada prakteknya dapat menimbulkan kerugian para pihak terutama pada pihak perempuan dan anak keturunan dari perkawinan yang tidak dicatatkan tersebut. 
Bunyi Pasal 2 ayat (1) : "Perkawinan adalah sah apabila dilakukan menurut hukum masing masing agama dan kepercayaan itu, dan ayat (2) Tiap tiap perkawinan dicatat menurut peraturan perundang-undangan yang berlaku."

Disini terdapat dualisme bahkan pluralisme norma. Satu norma hukum mengadopsi norma agama secara langsung melalui bunyi Pasal 2 ayat (1), sedangkan didalamnya terdapat ruang multi tafsir sedemikian luasnya. Karenanya pelaksanaan pencatatan perkawinan dalam ayat (2) tidak memiliki daya ikat integral sebagai satu kesatuan batang tubuh terhadap ayat (1). Pada akhirnya isi ketentuan dalam ayat (1) memiliki daya otonom sesuai tafsir dan pelaksanaannya agama masing masing, bahkan dapat menentukan suatu makna bahwa pernikahan adalah tidak mewajibkan mengenai pencatatannya kepada negara.

Dalam Pasal 5 ayat (1) Kompilasi Hukum Islam (KHI) menyatakan bahwa, agar terjamin ketertiban perkawinan bagi masyarakat Islam, setiap perkawinan harus dicatat." Bahkan dalam Pasal 6 ayat (2) tegas dinyatakan : "Perkawinan yang dilakukan diluar pengawasan pegawai pencatat nikah tidak mempunyai kekuatan hukum." Akan tetapi isi ketentuan ini berada dalam kamar atau ruang yang lain karena dalam Pasal 2 ayat (1) UU No. 1/1974 dinyatakan bahwa suatu perkawinan dianggap sah apabila telah sesuai dengan hukum masing masing agama dan kepercayaannya yang melakukan pernikahan.

Norma sosial mengenai kewajiban pencatatan pernikahan ini telah berubah dan semakin berkembang sesuai tuntutan jaman. Ketika interaksi antar manusia semakin tajam sehingga banyak hal lainnya yang perlu dijaga ketertibannya melalui peraturan perundangan undangan. Baik dalam kaitan administrasi kependudukan, hukum kepemilikan benda benda, hak dan kewajiban politik, kepentingan pendidikan, perbankan, dan lainnya. Kedudukan perkawinan tanpa pencatatan ini merugikan kepentingan para pihak terutama pihak perempuan dan anak turunnya karena dapat tidak memiliki kedudukan hukum yang cukup untuk menjalankan atau menikmati peran dalam eskalasi sosial mereka.

Berdasarkan hal tersebut, maka dari norma teologis dan norma sosial inilah terhadap kepentingan pencatatan perkawinan lebih kepada "kemauan/willingness" dan kesesuaian nya dengan tuntutan norma yuridis untuk melakukan pencatatan perkawinan, maka unsur pemahaman dan kesadaran hakikat perkawinan pada tiap tiap agama dan keyakinan pada diri masing masing pelaku pernikahan harus mengalami pengkajian maupun pendefinisan kembali untuk mencapai manfaat yang sebaik baiknya (mashlahat).

Dalam Alquran Surah An-Nisa 4:21 menerangkan, bahwa perkawinan adalah sebagai mitsaaqan ghalidan yakni suatu ikatan yang kokoh, suatu ikatan yang sangat kuat. Sehingga sebagai salah satu unsur guna memperkokoh pernikahan melalui pencatatan perkawinan yang diperlukan dalam eskalasi sosial adalah menjadi sangat fundamental. Kajian dalil yang menegasi selanjutnya dapat dibahas kembali setidaknya melalui metode maqashid syariah (legal reasoning) tentang alasan tujuan diturunkannya suatu syariat dari Tuhan kepada manusia, melakukan kajian interpretasi dan interelasi makna maksud antar ayat Al-quran maupun Al-Hadist dengan mempertimbangkan kepentingan saling silang (mubadalah) antar kepentingan lelaki dan perempuan agar berkeadilan. Sehingga pada saatnya nanti tidak ada lagi keinginan bagi para pelaku perkawinan dengan tidak mencatatkan pernikahannya karena hal semacam itu dapat dipandang merugikan kepentingan para istri, anak keturunan, dan kepentingan umum. 


\section{KESIMPULAN}

Pencatatan anak hasil nikah siri melalui Surat Pernyataan Tanggung Jawab Mutlak (SPTJM) adalah mengacu Permendagri No. 9/2016 tentang Percepatan Peningkatan Cakupan Kepemilikan Akta Kelahiran masih menimbulkan permasalahan hukum, tidak terpenuhinya akta nikah/kutipan akta perkawinan dan status hubungan keluarga pada KK yang tidak menunjukkan status hubungan perkawinan sebagai suami istri, maka data yang dicatat dalam kutipan akta kelahiran sang anak hanya nama ibu kandungnya saja. Tidak sekaligus mencantumkan nama bapaknya sebagaimana halnya dalam perkawinan yang sah. Sehingga sang anak masih memerlukan pembuktian siapakah bapaknya apabila diperlukan di kemudian hari. Disamping dalam upaya pembuktian akan banyak mengalami hambatan karena keberadaan KK baru melalui dokumen SPTJM memiliki kekuatan pembuktian yang lemah karena sebatas pengakuan sepihak penandatangan. Serta halangan halangan lain yang sengaja ditimbulkan para pihak yang berperkara. Kedudukan istri siri sendiri sangat rentan terhadap perlindungan hukumnya pula. Tidak adanya status kedudukan hukum sebagai istri yang sah maka belum timbul hubungan hukum timbal balik hak dan kewajiban sebagai pasangan suami istri. Pemenuhan hak dan kewajiban masing masing belum dapat menggunakan dasar tuntutan pemenuhan hukum melainkan hanya sebatas tahapan iktikad baik masing masing pihak.

\section{SARAN}

Perlunya menanamkan kesadaran hukum bagi masyarakat, Para pemuka agama atau orang yang mengawinkan (penghulu) juga bagi pelaku pernikahan untuk menanamkan keyakinan bahwa pernikahan adalah ibadah untuk mencapai manfaat yang sebaik baiknya (mashlahat) dengan mempertimbangkan kepentingan saling silang (mubadalah) antar kepentingan lelaki dan perempuan agar berkeadilan. Sehingga pada saatnya nanti tidak ada lagi keinginan bagi para pelaku perkawinan dengan tidak mencatatkan pernikahannya karena hal semacam itu dapat dipandang merugikan kepentingan para istri, anak keturunan, dan kepentingan umum.

\section{DAFTAR PUSTAKA}

Kurde, Nuktoh Arfani. 2005. Telaah Kritis Teori Negara Hukum. Pustaka Pelajar. Yogyakarta.

Mertokusumo, Sudikno. 2002. Pengantar Hukum Perdata Tertulis (BW). Sinar Grafika. Jakarta.

Nuruddin, Amiur \& Azhari Akmal Tarigan. 2004. Hukum Perdata Islam di Indonesia. Studi Kritis Perkembangan Hukum Islam dan Fikih. UU No. 1/1974 Sampai KHI. Prenada Media. Jakarta.

Prodjohamidjojo, MR Martiman. 2004. Tanya Jawab Undang-Undang Perkawinan. Pradnya Paramita. Jakarta.

Rizal, Jawahir Gustav . Pasangan Nikah Siri Bisa Punya Kartu Keluarga. Ini Kata Komnas Perempuan", https://www.kompas.com/tren/read /2021/10/08 /180000065/pasangan- nikah- siri-bisa-punya- kartu-keluarga-ini-kata-komnasperempuan?page $=$ all 
Sidharta, B. Arief. "Kajian Kefilsafatan tentang Negara Hukum. dalam Jentera (Jurnal Hukum). "Rule of Law". Pusat Studi Hukum dan Kebijakan (PSHK). Jakarta. edisi 3 Tahun II. November 2004.

Situmorang, Victor M. dan Cormentyna Sitanggang. 1991. Aspek Hukum Akta Catatan Sipil di Indonesia. Cetakan Pertama. Jakarta. Sina Grafika.

Susanto, Happy. 2007. Nikah Siri Apa Untungnya?. Visimedia. Jakarta.

Witanto, D.Y. 2012. Hukum Keluarga: Hak Kedudukan Anak Luar Kawin. Prestasi Pustaka. Jakarta.

Yunus, Mahmud. 1973. Kamus Arab Indonesia. Yayasan Penyelenggara Penterjemah/ pentafsiran Al-Qur'an. Jakarta. 